Int. J. Electrochem. Sci., 15 (2020) $2528-2538$

International Journal of

ELECTROCHEMICAL

SCIENCE

www.electrochemsci.org

\title{
The Performance of a Novel PdFe/B-N-G Catalys for Ethanol Electro-oxidation in Alkaline Medium
}

Wenhui Geng, Mengmeng Zheng, Dan Chen, Xianwen Wang, Zekai Zhang, Yishan Lin, Dongqin Cai, Huiqin Li, Guobo Huang, Yanxian Jin*, Binbin Yu*

School of Pharmaceutical and Material Engineering, Taizhou University, Taizhou 318000 , China

*E-mail: snowflakej@163.com

doi: $10.20964 / 2020.03 .48$

Received: 22 October 2019 / Accepted: 30 December 2019 / Published: 10 February 2020

Palladium catalyst $(\mathrm{Pd})$ are made attention to application in alcohol fuel cells due to unique performance, as well as the resource abundance and low cost, but the catalyst performance and stability of the catalysts are still not satisfied. In this article, the novel PdFe/B-N-G catalysts with the double element alloying and dual-doping for ethanol electro-oxidation are successfully prepared and determined by XRD, TEM and XPS. TEM results reveal a relatively uniform and high dispersion of Pd particles is observed on $\mathrm{PdFe} / \mathrm{B}-\mathrm{N}-\mathrm{G}$ catalyst. The XPS analysis indicates that $\mathrm{Pd}(0)$ contents of the $\mathrm{PdFe} / \mathrm{B}-\mathrm{N}-\mathrm{G}$ catalyst are increased on account of the $\mathrm{B}, \mathrm{N}$-doping effect. Being explored as the catalyst to the ethanol oxidation reactions, the $\mathrm{PdFe} / \mathrm{B}-\mathrm{N}-\mathrm{G}$ catalysts exhibit the better electrocatalytic activity with higher current densities and catalyst stability compared to those of $\mathrm{PdFe} / \mathrm{G}$ and $\mathrm{Pd} / \mathrm{B}-\mathrm{N}-\mathrm{G}$, which can be attributed to the synergistic effect of the enhanced $\mathrm{PdFe}$ alloying and the $\mathrm{B}, \mathrm{N}$-doping, that can produce more activity sites dispersing on the surface of graphene. Thus, the novel PdFe/B-N-G catalysts can be the potential alternate in alcohol fuel cells.

Keywords: Ethanol Electro-oxidation; PdFe catalyst; B, N doping; Alcohol Fuel Cells.

\section{FULL TEXT}

(C) 2020 The Authors. Published by ESG (www.electrochemsci.org). This article is an open access article distributed under the terms and conditions of the Creative Commons Attribution license (http://creativecommons.org/licenses/by/4.0/). 